\title{
A Rhapsody in Pink: Reflections on Seducing Nature through World Philosophies by way of James Joyce's Ulysses
}

DAVID JONES

\begin{abstract}
Through a reflection on color in the natural world by way of James Joyce's Ulysses, this paper is an ebullient, rhapsodic, and free-flowing associative meditation on the embodied place of humans in nature. Various sources are employed through a variety of philosophic literature: ancient Western, such as Heraclitus, Parmenides, Anaximander, and Plato; the Continental philosophical tradition, such as Nietzsche, Heidegger, Husserl, and Merleau-Ponty; and Asian sources, especially Buddhism (Dōgen and Thich Nat Hanh) and Daoism (Laozi and Zhuangzi). The meditation metaphorically opens with an encounter of the color pink, which is allegorically represented as our entry into the natural world, and how this color has been neutralized through its human intensification in the color red, which in its attempt to exaggerate pink and the natural accomplishes the opposite - the covering up the self-same reality of the world and the human place in the world. The liberation of the feminine by way of Joyce's character Molly Bloom is heralded as a call to turn again to nature's world as the only means of human redemption. This turn, or return, is a returning to the natural order by means of learning afresh how to seduce nature to love us as a species again; and in turn, nature holds out an existential challenge to our species - how to say yes, again and again, to who and what we truly are. And the what and who we are is to be in and a part of nature once again.
\end{abstract}

Keywords: embodiment; death; synesthesia; aesthesis; La petite mort; dukkha; yes 
JONES

INELUCTABLE MODALITY OF THE VISIBLE: AT LEAST THAT IF NO more, thought through my eyes. Signatures of all things I am here to read, seaspawn and seawrack, the nearing tide, that rusty boot. Snotgreen, bluesilver, rust: coloured signs. Limits of the diaphane. But he adds: in bodies.

$$
\text { - James Joyce, Ulysses }
$$

\section{Transparency - Limits of Diaphane-Adiaphane}

It should be said that in the beginning her lips were painted red. And they were painted this color for some reason. I realize I'm not entirely the reason, nor the reason at all, and maybe just a bystander reason (or a bystander of reason as we might say), but soon, but not soon enough, although I am patient, it is recognized that this red - this color of red - was not the true color of the occasion of its redness. Its truer color was pink. And as the red disappeared and got smeared into its vaguer hue, it revealed the truer pink of both lips. Pink, with a distant twinge of brown is sometimes a truer color of our movement together through the world. This pink is a greeting; it welcomes and embodies how and why we are here. It is as if this welcome is not always clearly expressed, or clearly received as it lies hidden in its concealment. There is often ambiguity, and this ambiguity is nature's way; it is nature's truth.

Our word "truth" is related etymologically to tree - harkening back to trēow (tree) in Old English. A tree is true when it is straight and wood gets trued with interaction by the artisan making caring changes along the wood's grain. Truth was once associated with nature, but nature's truth is a double bind, for it simultaneously says yes and no at the same time, as if the yes and the no somehow belong together, come together as a package neatly wrapped with ribbon and a lovely red bow placed on the top of life's ongoing present of life, and its other gift, death - the colors of death are different, but they too are the colors of life and nature's future life.

Yes, life is a gift (once from God before we killed him as Nietzsche proclaims) and this proffered present comes to us wrapped in colors of verdant greens, azure blues, glowing yellows, and sometimes in the silhouettes of blacks and greys. But these blacks and greys only have aesthetic dimension in light of the other colors of what they once were and will become the next day. The next day is nature's divinity - its unfolding into itself as something different. Heraclitus proclaims in a fragment that "The god is day-night, winter-time summer-time, war-peace, satiety-hunger (all the opposites, this is the sense) and 'he' is changed just as fire which when it is blended with that which is burnt 
[incense, spices] and it is named according to the pleasures of each." (Fragment 30) ${ }^{1} \mathrm{He}$ also discloses that even this "Sun is new each day." Godliness is the movement from the warm glowing colors of the day to the starkness of dark night - from the starkness of winter's short days to the effervescent glowing of summer's longer days and shorter nights; all of this along with the movement from the darkness of war to the light of peace and the darkness of being completely satiated is placed in counterpoint to the desiring light of hunger anew; nature says yes, oh yes, as our Penelope, Joyce's Molly Bloom, says in her reverie of life as she unveils red to pink. It now finally begins, and ends in Ulysses:

$O$ that awful deepdown torrent $O$ and the sea the sea crimson sometimes like fire and the glorious sunsets and the figtrees in the Alameda gardens yes and all the queer little streets and pink and blue and yellow houses and the rosegardens and the jessamine and geraniums and cactuses and Gibraltar as a girl where I was a Flower of the mountain yes when I put the rose in my hair like the Andalusian girls used or shall I wear a red yes and how he kissed me under the Moorish wall and I thought well as well him as another and then I asked him with my eyes to ask again yes and then he asked me would I yes to say yes my mountain flower and first I put my arms around him yes and drew him down to me so he could feel my breasts all perfume yes and his heart was going like mad and yes I said yes I will Yes. (783, italics added)

And I only add, the woman's word, yes, as Joyce would have it, is the yes to life.

And this yes to life is always in spite of suffering and its petition to move beyond the agonizing and unexpected trials that suffering brings; and this yes is to overcome our attachments that cause so much of this suffering. As the Buddhists realized in their pronouncement of $d u k k h a$ (suffering) as the First Noble Truth, our painful lack of ease in life is caused through our attachments, which are promoted by our desires (tanha a, thirst) - this is the Second Noble Truth. And suffering's removal is found in the Third Noble Truth (nirvāna). As Thich Nhat Hanh astutely responds to the First Truth of dukkha, "This is the starting point of all Buddhist practice. If we are not aware that we are unwell, we will not know to seek treatment, and we cannot be healed." (Hanh1998: 30) Joyce deeply senses life's suffering and the acute need for healing in his Ulysses. ${ }^{2}$

1 All unattributed translations of the Greek are mine.

2 Joyce was aware of Buddhism mainly through Theosophy, which has a more mystical inclination than Buddhism. Buddhist tenets are often in his characters, especially in Finnegans Wake and also in Ulysses. Joyce, however, did not need Buddhism to understand that life is suffering. Nevertheless, his response to suffering is very Buddhist in nature, with its conduit for self-overcoming being the feminine as suggested here. 
JONES

There remained the generic conditions imposed by natural, as distinct from human law, as integral parts of the human whole: the necessity of destruction to procure alimentary sustenance: the painful character of the ultimate functions of separate existence, the agonies of birth and death: the monotonous menstruation of simian and (particularly) human females extending from the age of puberty to the menopause: inevitable accidents at sea, in mines and factories: certain very painful maladies and their resultant surgical operations, innate lunacy and congenital criminality, decimating epidemics: catastrophic cataclysms which make terror the basis of human mentality: seismic upheavals the epicentres of which are located in densely populated regions: the fact of vital growth, through convulsions of metamorphosis, from infancy through maturity to decay. (697)

Molly's yes is her acceptance of everything as natural. She is the life-force that makes her the faithful Penelope, but this time to the earth and not devotedly awaiting the return of some warrior husband, for she is the eternal spirit of life, the eternal Spirit of Life overcoming "the generic conditions imposed by natural ... law ... as integral parts of the human whole ... through conclusions of metamorphosis, from infancy through maturity to decay” (Joyce 1961: 697). Joyce's Penelope, Molly, awaits not for a hero warrior's return, but rather, she looks to herself, to the archetype of Gaia within, and bequeaths and communes a life affirming "yes." Her affirmation is the sense of Chapter 6 in the Daodejing:

The life-force of the valley never dies -

This is called the dark female.

The gateway of the dark female -

This is called the root of the world.

Wispy and delicate, it only seems to be there,

Yet its productivity is bottomless. (Ames and Hall 2003: 85)

With the life-force that is her and the inner "dark female" she is at "the root of the world", Molly overcomes the mistaken and deluded sense of self, that is, an anthropocentric, substantial, and ego-infatuated self separated from its body through some kind of Cartesian precision - this is the self that occludes the very life from which it has risen. In the Genjo Kōan, the first fascicle and central introduction to Zen master Dōgen's Shōbōgenzō, expresses it this way: "To study the buddha way is to study the self. To study the self is to forget the self. To forget the self is to be actualized by the myriad things." (Tanahashi 1985: 70) The myriad things are the ten thousand things of the world, that is, the totality of all that is. Molly's "yes" reminds both men and women to locateto re-locate unremittingly - the Gaia within as a means for re-entering the nearness of Earth, our world. 
This yes is a yes to the primary color of pink, the faded hue of red in various formulations that is embellished in our aesthetic response to the natural world. We exaggerate our experience in the world, our Lebenswelt, and this tendency on our parts may be necessary for us, for it makes and allows for our myths, narratives of self, gender identities, and how to go about living with each other and all those creatures in the world surrounding us. Our myths bring us back in and back to our species-ial being, our special being, that can learn to say yes, again, and again yes. A yes to the pre-human time when we evolved this larger brain - yes, to this larger brain - and where we would learn to "depend more on vision and less on smell than did other mammals" - and yes, and again, yes to those "large eyes with color vision, which were placed forward on the head to give binocular vision and a better sense of depth." (Wilson 2012: 23) And "yes" to the world that surrounds us in its multifarious and multihued splendor. But this yes concomitantly comes as a denial of a separate and distinct self that has evolved to be full of itself.

The thought of nature as a surrounding, as circumscribing the human, is an odd one because the world does not surround us except from the human perspective. We are in the world, encased by it, and enfolded into it. And we are no longer surrounded by the world once we gain the perspective that we (the "I" in plural) are not primary - not primary like the color red, but rather the color of nature's pink. We exaggerate the self, our selves, first in psychological terms and subsequently ontologically. But what does nature care of our exaggerations? Her answer rings clearly as a bell on a windless and clear night.

Our senses connect us to the world as a place of which we are a part, a world in which we think we are surrounded by the blueness of the day's sky and the greens, browns, reds, blues, yellows, and so on - we cannot even keep up with all the world's colors, but they invite us in, make us understand the finer distinctions of all that is, and reach out for us to "enter the nearness," as a spurious fragment of Heraclitus decrees. But who cares about the spurious when one is confronted with the world in which she has found herself - a world that challenges humans to become resonant with its inherent and immanent wisdom of its life, and its death? And what is the color of this death? Is death's color a black nothingness? Is this only the singularity of one's own death perspective failing to see and smell its own rotting flesh down to the pink of the hypodermis? Is this only a failure to see one's decaying bones in colors much different from black nothingness? From a personal perspective we can only imagine. Or, we can move along with Joyce: 
JONES

Evening hours, girls in grey gauze. Night hours then black with daggers and eyemasks. Poetical idea pink, the golden, then grey, then black. Still true to life also. Day, then the night. (Joyce 1961: 69) ${ }^{3}$

Heidegger realized death was better seen as possibility instead of the less philosophically interesting facticity of death's occurrence - endings need experiencing for them to be endings at all, and our final act plays out without us. Death represents something unthinkable for Dasein, even in its longitudinal stretching out along its trajectory toward death. The impossibility of this trajectory toward ending is in essence an opening up, an opening of possibility, and a fresh beginning. As Nietzsche's Zarathustra realizes in "The Three Transformations" that beyond the abject nihilism of the camel and the active nihilism of the lion's roaring "Nay" lies a sacred yes of the child:

Innocence the child is and forgetting, a beginning anew, a play, a self-propelling wheel, a first movement, a sacred Yea-saying.

Yes, for the play of creating, my brothers, a sacred Yea-saying is needed: the spirit now wills its own will, the one who has lost the world attains its own world. (Parkes 2005: 24)

For Freud, this is expressed more negatively as the fear of death, which is "an analogue of the fear of castration" - the unimaginable loss for young boys, or men. But what is the seeing of death that can be imagined?

The black nothingness of death should remind us of the dark emptiness where we see in the brain; this reminder is also an existential possibility. When we perceive an object, it is our retina (located at the base or back of the eye) that sends electrical impulses streaming to the visual cortex of our brains. Without the visual cortex part of the brain, we would not see. However, this part of the brain 'sees' no light and remains for a complete lifetime in the dark and in a color deprived darkness like that which Plato's cave prisoners experience at the beginning of Book VII of his Republic. This darkness is associated with ignorance, the absence of truth. The retina itself, without the visual cortex, does not perceive anything either since it is just a processor of the information sent to it from the photon field of vision in front of the eyes. Some of the mystery of the sensual self's perceptive state of being is evoked by Francis Crick in The

3 In "The Drunken Song” of Thus Spoke Zarathustra this sentiment also rings true. With his "honourable animals the eagle and the serpent", Zarathustra meets this challenge after becoming aware of the night befalling "still all around and mysterious; but from the depths there slowly arose the sound of a bell.... 'Come! Come! It is close to midnight!' and his voice had been transformed.... 'Come! Come! Come! Let us now wander! The hour is here: let us wander into the night!’” (Parkes 2005: 279) 
Astonishing Hypothesis where he explains the use of various optical illusions and misperceptions as tools in neurological and psychological research on visual perception. Vision, contrary to what many imagine, is not analogous to a television set playing inside the brain. Just as Buddhists, such as Thich Nat Hanh, suggest, neuroscience reveals that the "object of seeing" is itself an illusion. ${ }^{4}$ In Crick's words:

Thus, what the brain has to build up is a many-leveled interpretation of the visual scene, usually in terms of objects and events and their meaning to us. As an object, like a face, is often made up of parts (such as eyes, nose, mouth, etc.) and those parts of subparts, so this symbolic interpretation is likely to occur at several levels. (Crick 1994: 33)

Two paragraphs later he concludes:

It is difficult for many people to accept that what they see is a symbolic interpretation of the world - it all seems so like 'the real thing.' But in fact, we have no direct knowledge of objects in the world. This is an illusion produced by the very efficiency of the system since, as we have seen, our interpretations can occasionally be wrong.

The mutual cooperation between the retina and visual cortex gives us seeing, but what is this seeing that is seen? Is it the nature of reality? We know a lot already from physics and even from our own experiences of the world. If we reflect phenomenologically on them, we soon realize the so-called reality outside of ourselves is equally complex. By themselves, our manufactured images of self/world/universe are something far from the practical sense we typically attribute to them, for they give us nothing but a fabricated world of self/other; and it is precisely this world that has been called into question by Daoist writers and especially by Buddhist thinkers after they come into interface with indigenous Chinese philosophy. Combining the wisdom of Hanh and Crick, we could say that feeling as one with our brain's explicit symbolization of the world around us is as close as we can approach an intimate human participation in the "real world". Along with Nietzsche, Hanh and Crick deny any little self, a homunculus, residing inside of us.

Joyce realizes that "In the midst of death we are in life. Both ends meet" (1961: 108) and with the wisdom of a gravedigger that death fertilizes life, he describes a burial conversation:

4 See throughout Hanh 2003. 
JONES

Chinese cemeteries with giant poppies growing produce the best opium.... The Botanic Gardens are just over there. It's the blood sinking in the earth gives new life. ... I daresay the soil be quite fat with corpse manure. Bones, flesh, nails, charnelhouses. Dreadful. Turning green and pink decomposing. Rot quick in damp earth. The lean ones tougher. Then a tallowy kind of cheesy. Then begin to get black, treacle oozing out of them. Then dried up. Deadmoths. Of course the cells or whatever they are go on living. Changing about. Live for ever practically. Nothing to feed on feed on themselves.

But they must breed a devil of a lot of maggots. Soil must be simply swarming with them. (108)

This is death in nature, in nature's world - that world that surrounds us and ultimately claims us just as the dove caught in the grasp of the red-tailed hawk's talons is unexpectedly seized. We are here, waiting to be seized by death. But our waiting is always existentially my waiting. Life has its own talons that will, as Heraclitus says in Fragment 66, "seize one unexpectedly". I will be seized as I am seized by the real color of those pink lips - top to bottom, bottom to top and my being seized needs to be a joyous movement in both the La petite mort and the Great Death. First Death's child's death -

\author{
La petite mort \\ When you cum (Be a good girl) \\ Hold your breath (Make it last long) \\ it's a mess (And it's called) \\ The Little Death Girl
}

So please, When you die could you scream?

Mercy, Mercy for you and me

Its true What they say, fuckin' for

love might be the last legal drug

(Korn)

In the high noon of psychoanalysis, Freud would bring Thanatos to shoot it out with Eros. "In short," Freud says of these drives, eros is "to bind together; ... [and of thanatos it is] to undo connections and so to destroy things." (Freud 1949: 5) In a letter to Jung, Freud would write that "Psychoanalysis is in essence a cure through love" and we should be reminded of Spinoza's "joy"

5 Opening epigram in Bettelheim 1984, in which he accentuates a 6 December, 1906 letter from Freud to Jung that reads "Essentially, one might say, the cure is effected by love" (McGuire 1974: 12) and is in reference to transference being a necessary condition in understanding the operations of the unconscious. 
and "sorrow" that drive all other passions. Our desire to "fuck for love", "our last legal drug", as Korn sings, is to bind together where we can learn to "establish even greater unities and preserve them" (Freud 1949: 5). This is the Great Death of the Buddhists that positions us in the ongoing flow of all that is. The color of death is not black, often thought of as the absence of color, but it is the rejuvenation, or rebirth, of color. Even the Black Plague of Death gives birth to those blues, reds, yellows, browns, purples, and yes to those future pinks that we exaggerate as reds - held out to death in their hyperbolic redness - and symbolized as sexuality. Like the relational sense of the little death, the Chinese knew life is always death for death is life, and life is death, and our color scheme finds its way somewhere in between. ${ }^{6}$ The in-between-ness of color in life and death's flow was understood by the ancients as a form of justice that mediates the movement of the elements into constantly reconfigured patterns. As Anaximander expresses in his surviving fragment: That from which all things are born is also the cause of their coming to an end, as is meet, for they pay reparations and atonement to each other for their mutual injustice in the order of time (de Santillana 1961: 22, italics in original). Our coming to be is an injustice for

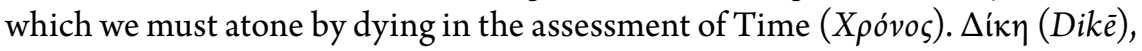
Justice, is nature's custom, its ongoing practice, once we are secreted from $\tau$ ò ä $\pi \varepsilon ı \rho v$ (to apeiron), that which is without beginnings or ends; we are spawned

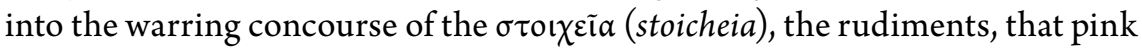
place of elemental opposition from which we all emerge, and to where we all return to in its darkness.

\section{Poetic Idea of Pink}

Although I try to eradicate saying "I", let me say "I": When I decided to listen as carefully as I could to Molly, I soon realized that to love life comes with a caveat, for it also requires us to love death. To love the vibrancy of colors our senses present to us is to traverse across them as bridges back to the world; these colors are trying to get into this conceptualizing being that we have become - being a being with such a proportionately large brain is our synchronized blessing and curse. We attempt to keep the multitude of color out with our belief in

6 In Chinese cosmology and philosophy, the inter-relationality of opposites is perhaps best represented by yin and yang as seen in the Tàijí 太極 symbol. Daodejing 42 is a good example: "Everything carries yin and yang in its arms/ And blends these vital energies ( $q$ i) together to make them harmonious (he)" (Ames and Hall 2003: 143). This tendency toward unity in difference is emblematic of all schools in ancient Chinese philosophy. 
JONES

transcendent realities of heavens and hells, with some kind of unequalled and otherworldly God that finally becomes too irrational, irresponsible, and unfeeling for belief by any rational and sensing being. The reality of that $\mathrm{He}$-God has become simply unimaginable. But our Penelope, true to the earth, speaks to us still when she says,

I love flowers Id love to have the whole place swimming in roses God of heaven theres nothing like nature the wild mountains then the sea and the waves rushing then the beautiful country with the fields of oats and wheat and all kinds of things and all the fine cattle going about that would do your heart good to see rivers and lakes and flowers all sorts of shapes and smells and colours springing up even out of the ditches primroses and violets nature it is .... my God after that long kiss I near lost my breath yes he said I was a flower of the mountain yes so we are flowers all a womans body yes that was one true thing he said in his life and the sun shines for you today yes. (781)

This sun of the immanent god is expressed in woman's word, the woman's yes to life, and it is the yes to the divinity of the emergence of "the best of all possible worlds", our only world. To be "flowers of all a womans body" is to will that we "shall not enter that Kingdom of Heaven ..." and as Zarathustra adds, "But then we do not want to enter the Kingdom of Heaven at all: we have become men - and so we want the Kingdom of Earth." (Parkes 2005: 276) To become this kind of "man" is to realize the inner Gaia. Along with Spinoza, we must learn to say yes to Deus sive natura, and realize the interchangeability of the two terms. Yes, we need to imagine; and yes, we need to create myths. Although unbelievable and unreal in the strictest sense, the myths of the ancients were most real in their reality of their there-being and of who we are. There is no world-less subject that is just one of the thing-like definable entities of the world - Heidegger's existential analytic eradicates this sense of subjectivity for we are beings-in-the-world where we are there-beings or beings-there; we are in a world of color for those of us who can learn to finally see through its vivid spectrum and learn to give mythic expression in tandem with our science.

To grow weary of the colorless promises of the eternal where everything is in black and white is to enter Molly's world. The black and white is the colorlessness of right and wrong - dualism shorn of color that has forfeited all the subtle nuances of the complexity that is real, or the reality of any situation: ethical, social, political, and so forth. The Zhuangzi text defines this dualism as the "this and that's" or "it" and "others" of our made-up world and its will to simplicity, will to comfort, will to stasis, and its will to mediocrity. As we see in the Zhuangzi, the idea is, of course, to overcome the dualistic tendencies we have developed in our patriarchal transcendence from nature. 
"This" is also a "that." "That is also a "this." "THAT" posits a "this" and a "that" a right and wrong - of its own. But "THIS" also posits a "this" and a "that" - a right and wrong - of its own. So is there really any "that" versus "this," any right versus wrong? Or is there really no "that" versus "this"? When "this" and "that" right and wrong - are no longer coupled as opposites - that is called the Course $[D a o]$ as Axis, the axis of all courses [daos]. When this axis finds its place in the center, it responds to all the endless things it confronts, thwarted by none. For it has an endless supply of "rights" and an endless supply of "wrongs." Thus, I say, nothing compares to the Illumination of the Obvious. (Ziporyn 2009: 12)

This dualism that we have scored onto our souls is colorless, without meaning in any true sense of meaning's ambiguity. We only want the Truth, not nuance; reality, not gesture; knowledge, not understanding - and this has become our visionless state of which we should be uneasy and weary; we are self-indulgent beings who embrace color difference but not the richness of color's diversity for the pink changes in degree when we move across the pigmentation of what it means to be human, and from the excitement, or even reticence, of the individual within any group. To love pink is to love life, to love nature, and absolve oneself from the categories of self-imposed knowing that render difference, yes difference, as being different, nonhuman, unnatural, and ultimately other. The ethics of color prefers gesture to reality, ambiguity to truth, and understanding to knowledge - and a superfluity of rights and wrongs.

Nature is bold, she forces us to breathe deeply in remembrance of the yet to be last breath that is on the horizon of our lives - always an exhale as Homer knew - and one wonders what the color of invisible breath might be. But it is this very invisible color of breath that brings life's colors into us. To be sighted brings joy to us, and for those who are sighted should be thankful for being able to see. With our bodies now the oldest they have ever been, we should see as we have never seen before. We can spend time seeing the flower's petals and its pistils, those ovule bearing female organs that present themselves in singular form in a lily or hibiscus or in multiple forms as in a buttercup - we have seen the white of the lily, the red of the hibiscus, or the yellow of the buttercup in our mind's eye but the white was not completely white (perhaps there were tinges of brown or yellow therein) and that red hibiscus might have been a yellow or white one with stamen and pistil in yellow and red. Molly "was a flower of the mountain" and "yes ... we are flowers all a womans body."

Colors are not pure in themselves or in the mind's imagination, for we imagine the world in which we are, and this imagination of the world in which we are is perceived. For color has no being in nature, "At least ... in the form the untutored brain thinks. Visible light consists of continuously varying wavelengths, with no intrinsic color in [the visible light]." Our "Color vision 
JONES

is imposed on this variation by the photosensitive cone cells of the retina and the connecting nerve cells of the brain." (Wilson 2012: 205) In other words, we imagine the world of color through our perceptual apparatus. To touch this color, to apprehend color, and to speak color is the logos for rhapsodies of pink.

\section{Shutting Our Eyes to See}

The leaves of those flowers and their veins of life, the colors in the veins of a rock, and sometimes when we're lucky we can smell these colors that "are named according to the pleasures of each," or taste the grapes' color as we slowly absorb a Brunello or Barolo. Even in his suburban way, Merleau-Ponty was aware of the synesthesia of the senses - at some point the senses must overlap, blend together with each other. Sounds have color and feeling, smells have colors, touches have colors, our feelings seem to have color, our tastes have color - and how we should love when that color is pink, for this taste is the color of life. And as the human animal - that brainy biped we have become - we are dominated by this sense of sight at the expense of all others. This domination finds its grounding in Parmenides and Plato. Plato's highest Idea, The Good, is symbolically represented in his "Allegory of the Cave" as the Sun - and from the Abrahamic tradition we know that this God is Good and is the Light. For Parmenides, the Truth is revealed, brought out of its concealment, and made visible to the young traveler in search of the Truth. But there was a time before the Platonic grasp on the soul individuated it and made it distinct from the body; a time before it rendered the body's knowing through the senses inferior; and there too can be a time after when we realize the synesthesia of the senses.

As John Sallis notes:

Poetry - and not only in the form of words set to music - comes closer to matching what is heard, or rather, to supplementing it in a manner that aids or even enhances its truth. Listen to the opening strophe of a poem by David Pollard that adopts as its own the title by which Beethoven described the slow movement of his A-minor quartet (opus 132), the title Heiliger Dankgesang. ${ }^{7}$ (Wirth, Schwartz, and Jones 2016: 191)

\section{Listen-}

the notes have colours,

sighs of ruby shellac glow in wineskin augmented to dark malachite and verdigris in fifths with lamp black harmonies

See David Pollard's Risk of Skin (Hove: Waterloo Press, 2011, 16). 
A Rhapsody in Pink

\author{
between \\ exactly burns \\ in rising unisons \\ the certainty of loss.
}

that sing into their perfect place

We listen, we look, but we do not often look to see, or hear to listen. As Joyce apprises us of the inevitable ways in which we see things, "Shut your eyes and see." (1961: 37) Looking is to listen with the eyes, listening is to see with the ears. Color in nature forces us to look to the world, towards the world, to the red berries protruding from the leaves surrounding them - this is our perspective of other things in the world, that they are surrounded, feel surrounded, or project their surrounded-ness. What do the red berries know of the leaves or even of their redness. Their red moves in the wind as I write these words, forcing me to pause to look, to listen, to get up and go outside into the world, to listen to the rushing north wind on this day and smell what it carries along its way, even as far as my arm chair suburbia. When did we start philosophizing without poetry?

Parmenides, the father of rationalism, wrote a poem about a youth driven by maidens and mares to a Goddess who reveals to him the truth. Truth was once a disclosing event with the force of revelation and it took the imagination and its eros great strides to reach this truth. Hesiod was also aware of eros and the imagination when he wrote in his Theogony: "First of all the Void [Chaos] came into being, next broad-bosomed Earth, the solid and eternal home of all, and Eros..., the most beautiful of the immortal gods, who in every man and god softens the sinews and overpowers the prudent purpose of the mind" (Brown 1953: 56). This is the eros Freud knew so well from his study of the Greeks, for as he tells Jung, "The ancients knew how inexorable a god Eros is." (McGuire 1974: 11) The birth of the goddesses and gods was the birthing of the aesthetic imagination, and it is through our senses and imagination that we enter our world, and the world presents herself in living, and dying, color.

Hegel too was aware of the aesthetic imagination when he begins his lectures titled Aesthetics by observing the un-satisfactoriness of its title. As Sallis notes, "In Hegel's view, the title conveys an entirely superficial conception of what, more properly, should be called philosophy of art." (Wirth, Schwartz, and Jones 2016: 195) Our general move as a species has been to denigrate the epistemological significance of the imagination and its reliance on the embodied senses. Our word aesthetics has its etymological foundation in the Greek alo $\theta \eta \sigma ı \varsigma$ (aisthesis), which means perception. Our senses, our invisible bridges to the world, imaginatively order our experiences into meaningful images and imagine patterns emerging from the manifestations of and in nature. We give the world meaning; it is our gift to the world and our mutual gift from the world. 
JONES

To give or receive this gift we must realize along with Husserl that our intentionality, or directedness toward, is without intent, without any intending, for it is a longitudinal stretching of our intentionality and that as subjects we are nothing other than time and its unfolding - the time of Anaximander's chreon,

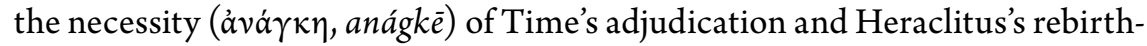
ing of Time's patterning.

Since the time of Plato, we tend to be dominated by sight and seeing with color and its difference as our primary and dominate means of knowing our world. In the Phaedo, Socrates presents the earth as a globe placed at the center of the heavens and is maintained in this position by some balanced perfection, but what we call our earth is decreed an imperfect thing (Jowett 2012: 109). As Jowett explains in an elegant paraphrasing of Plato in his classic translation of the Phaedo,

... the true earth is above, and is in a finer and subtler element. ... Our earth is everywhere corrupted and corroded; and even the land which is fairer than the sea, for that is a mere chaos or waste of water and mud and sand, has nothing to show in comparison of the other world. But the heavenly earth is of divers colours, sparkling with jewels brighter than gold and whiter than any snow, having flowers and fruits innumerable. And the inhabitants dwell some on the shore of the sea of air, others in "islets of the blest," and they hold converse with the gods, and behold the sun, moon and stars as they truly are, and their other blessedness is of a piece with this. (Jowett 1892: 111) ${ }^{8}$

The idealized and heavenly earth is vivid and rich in color, even Plato loved color in the best Sony Trinitron could offer - colors far-reaching into flowers and fruits and the inhabitants are blessed because they can behold the celestial bodies in their full abundance as opposed to those living on our earth. For Plato, we need the higher perspective found in his Phaedo:

In the first place, the earth, when looked at from above, is in appearance streaked like one of those balls which have leather coverings in twelve pieces, and is decked with various colours, of which the colours used by painters on earth are in a manner samples. But there the whole earth is made up of them, and they are brighter far and clearer than ours; there is a purple of wonderful lustre, also the radiance of gold, and the white which is in the earth is whiter than any chalk or snow. Of these and other colours the earth is made up, and they are more in number and fairer than the eye of man has ever seen; ... And in this fair region everything that grows - trees, and flowers, and fruits - are in a like degree fairer than any here; and there are hills, having stones in them

8 For the passage referred to see Jowett 2012: 105. 
in a like degree smoother, and more transparent, and fairer in colour than our highly-valued emeralds and sardonyxes and jaspers, and other gems, which are but minute fragments of them: for there all the stones are ... pure and not like our precious stones, infected or corroded by the corrupt briny elements which coagulate among us, and which breed foulness and disease both in earth and stones, as well as in animals and plants. (Jowett 2012: 106)

The human challenge for Plato seems to be how to perceive in a godlier way so we too may see "the radiance of gold, and the white which is ... whiter than any chalk or snow." Plato aspires to a superior realm beyond the human capability and its anchor in the body. In the Phaedrus, the ascent of the soul is described and Socrates reveals to Phaedrus that the successful souls ascend to the "summit of the arch that supports the heavens.... It is there that true Being dwells, without colour or shape, that cannot be touched; reason alone, the soul's pilot, can behold it, and all true knowledge is knowledge thereof." (Hackforth 1982: 78) Being is without shape and color - and to be without color and shape is simply to be nothing, to be nothing in nature. Reason, the true eye of Plato's tripartite soul, sees, but it sees no color, shape; it sees only nothing.

Sight is the selective sense as Gadamer observes - we can look away at will, but we cannot hear away at will. But what of those who want to blend their sight with hearing, smelling, touching, and tasting in a world dominated by seeing? Are we the mad men and the insane women who must light lanterns at noon and run into the market place as Nietzsche's muezzin does proclaiming the death of God?

With all of our differences in sensing and sensible awareness, are we excommunicated to the place of some Husserlian eidetic reduction where color is completely a subjective phenomenon? Are we left with the rupture between mathematical representations of color and their scientific understandings, even if they are beautiful and elegant? Are we to remain color blind to the world by seeking only those universal forms of phenomena that are available to science and mathematics? Or are we to let the world in by reaching out through our senses, to inhale the colors, smell their assorted fragrances, hear their warmth and coldness, to feel: aqua, azure, amber, burgundy, burnt orange, cadmium green, celadon, crimson, dogwood rose, forest green, golden poppy, Honolulu blue, jade, jasmine, jasper, lavender indigo, midnight blue, olive, orchard, peach, pear, pumpkin, quartz, raspberry, saffron, tropical rainforest, vanilla, vermillion, wild strawberry, wisteria, xanadu, and zaffre.

And are we yet able say the woman's yes with Molly? Are we able to let the world in by learning to once again imagine the taste of the color pink? 
JONES

Can we put our arms around her yes and draw her down to us so we could feel her breasts all perfume yes and have our hearts going like mad and finally say yes to her, yes to Gaia, yes I will - I will Yes.

\section{David Jones}

djones@kennesaw.edu

Kennesaw State University

USA

\section{References}

Ames, R. T., Hall, D. L. 2003. Daodejing "Making This Life Significant": A Philosophical Translation. New York: Ballantine Books.

Bettleheim, B. 1984. Freud and Man's Soul. New York: Random House.

Brown, N. O. 1953. Theogony. Indianapolis: Bobbs-Merrill Company.

Crick, F. 1994. The Astonishing Hypothesis: The Scientific Search for the Soul. New York: Simon and Schuster.

Freud, S. 1949. An Outline of Psychoanalysis. New York: W.W. Norton.

Hackforth, R. 1982. Plato's Phaedrus. London: Cambridge University Press.

Hanh, Thich Nhat 1998. Interbeing. Berkeley, CA: Parallax Press.

Hanh, Thich Nhat 2003. Buddha Mind, Buddha Body: Walking Toward Enlightenment, Berkeley, CA: Parallax Press.

Joyce, J. 1961. Ulysses. New York: Vintage Books.

Jowett, B. 2012. Phaedo. Scotts Valley, California: CreateSpace Independent Publishing Platform.

McGuire, W. 1974. The Freud/Jung Letters: The Correspondence between Sigmund Freud and C.G. Jung. Princeton, New Jersey: Princeton University Press.

Parkes, G. 2005. Thus Spoke Zarathustra. New York: Oxford University Press.

Pollard, D. 2011. Risk of Skin. Hove: Waterloo Press.

Sallis, J. 2016. When Words Come to Bear. - J. M. Wirth, M. Schwartz, D. Jones, eds., On the True Sense of Art: A Critical Companion to the Transfigurements of John Sallis. Evanston, Illinois: Northwestern University Press, 190-204. https://doi. org/10.2307/j.ctv47wd0d.19

De Santillana, G. 1961. The Origins of Scientific Thought from Anaximander to Proclus 600 B.C.-500 A.D. New York: The New American Library of World Literature.

Tanahashi, K. 1985. Moon in a Dewdrop: Writings of Zen Master Dōgen. New York: North Point Press.

Watson, B. 1964. Chuang Tzu: Basic Writings. New York: Columbia University Press

Wilson. E. O. 2012. The Social Conquest of Earth. New York: Liveright Publishing.

Ziporyn, B. 2009. Zhuangzi: The Essential Writings. Indianapolis: Hackett Publishing Company. 